FIU Law Review

Winter 2007

\title{
Ask Not What Your Government Can Do for You, Ask What Your Government Can Do for Small Business: A Proposal for Government Involvement in the Securitization of Conventional Small Business Loans
}

Eduardo F. Rodríguez

Follow this and additional works at: https://ecollections.law.fiu.edu/lawreview

Part of the Other Law Commons

Online ISSN: 2643-7759

Recommended Citation

Eduardo F. Rodríguez, Ask Not What Your Government Can Do for You, Ask What Your Government Can Do for Small Business: A Proposal for Government Involvement in the Securitization of Conventional Small Business Loans, 2 FIU L. Rev. 143 (2007).

DOI: https://dx.doi.org/10.25148/lawrev.2.1.13

This Comment is brought to you for free and open access by eCollections. It has been accepted for inclusion in FIU Law Review by an authorized editor of eCollections. For more information, please contact lisdavis@fiu.edu. 


\title{
Ask Not What Your Government Can Do for You, Ask What Your Government Can Do for Small Business:
}

\section{A Proposal for Government Involvement in the Securitization of Conventional Small Business Loans}

\author{
Eduardo F. Rodríguez ${ }^{1}$
}

America's small businesses-some twenty million strong-are the strength of our nation's economy. They account for thirty-nine percent of the country's gross national product, create two out of every three new jobs and produce two and one half times as many innovations per employee as do large firms. ${ }^{2}$

I. Introduction 144

II. Background

A. The History of Securitization

B. The Intricacies of a Securitization Transaction

1. Selecting and Enhancing the Pool of Assets.

2. Striving for a Bankruptcy Proof Special Purpose Vehicle.......157

(a) Bankruptcy Remoteness: True Sale, Substantive

Consolidation, and Fraudulent Conveyance.

i. True Sale Characterization

ii. Equitable Doctrine of Substantive Consolidation

\footnotetext{
${ }^{1}$ Associate, Lamelas \& Carballo, P.A., Miami, Florida. J.D., May 2006, Florida International University College of Law; M.S., Finance, August 2003, Chapman Graduate School of Business, Florida International University; B.A., Economics, April 2002, Florida International University. Many thanks to Professor José Gabilondo for his encouragement and guidance as my Faculty Advisor. Additionally, I would like to thank the world's greatest Student Editor, Kim Donovan, for her support and feedback during this process. I thank my wife, Ofelia, for her infinite patience and undying support no matter how difficult or tedious the task I choose to embrace. And to my son, E.J., you are too young to understand why your dad is always studying, but I hope that it will serve to make your life as enjoyable and meaningful as possible. Finally, my efforts on this comment are dedicated to my father, Aristides F. Rodríguez, who I miss more than words can express.

2 Small Business Administration Office of Advocacy Mission Statement, available at http://sba.gov/ADVO/mission.html.
} 
(b) Bankruptcy Proof? Eliminating Potential Entity

Risks

C. Why Firms Securitize their Assets...........................................163

III. Analysis

A. Creation of a Government-Sponsored Entity .............................166

B. Adoption of Credit Scoring Models

C. Government Guarantee of Conventional Small Business Loans...171

IV. Conclusion 172

\section{INTRODUCTION}

Small businesses are responsible for the creation of most new jobs, particularly in a struggling economy. During political campaigns, politicians tout their records on creating jobs and implementing programs that support small business. Government has historically been able to help small businesses by creating programs that finance small businesses and ensuring government contracts for small businesses. The Small Business Administration [SBA] is viewed as the Government's greatest example of its support for small business. While the SBA has created many excellent programs that help finance small businesses and educate small business owners about the management, financing, and expansion of their businesses, there is still more that the Government can do to support small business. For example, the creation of a successful and efficient secondary market for conventional small business loans can provide new and exciting opportunities for financing small businesses. Like with other forms of securitization, the Government is best-equipped to support such an initiative thanks to their impeccable credit ratings and past experiences with securitization.

Small business owners look to many different sources for financing the start-up, ongoing, and growth related costs of their business. There are two basic forms of financing - equity and debt. Typically, new small businesses rely on equity financing in the form of savings or personal loans. Financing through small business loans is, at times, hard to come by for entrepreneurs. SBA programs have served small businesses for over fifty years and provide excellent opportunities for small business owners. Conventional small business loans that are originated by commercial and community banks alike are typically reserved for those small businesses that are well established and enjoy excellent credit histories.

Minority-owned small businesses are less likely to secure financing through these conventional small business loans than non-minority-owned 
small businesses. ${ }^{3}$ While disproportionate access to small business credit is partly a function of industry trends and the greater risk that is involved in lending to minorities, statistical studies have shown that after controlling for factors such as creditworthiness, wealth, education, and others, minorities are discriminated against when banks issue small business loans. ${ }^{4}$ The beginnings of improving access to small business capital for minority business owners may lie in improving the secondary markets for conventional small business loans. Given the importance of small businesses, and in particular minority small businesses, ${ }^{5}$ to the future prosperity of the United States economy, it is time the Federal Government installed programs similar to those in the residential and commercial mortgage secondary markets in the arena of small business loans.

This comment will propose what is needed in order to successfully and efficiently securitize conventional small business loans. Drawing on the experience of the mortgage secondary markets, this comment will make several recommendations as to the level of government involvement needed in order to effectuate an efficient secondary market for small business loans. Moreover, this comment will make recommendations to improve the overall lending environment that will make small business loans more marketable to investors in asset-backed securities.

3 The Minority Business Development Agency provides several reasons for such a discrepancy. Ronald Langston, Report of the Summit on Minority Business Financing, Accelerating Job Creation and Economic Productivity: Expanding Financing Opportunities for Minority Businesses, U.S. Department of Commerce Minority Business Development Agency, 11 (2004), available at http://www.mbda.gov/documents/Report_Cover.pdf. Some of these reasons are firm specific, such as equity capitalization, creditworthiness, owner education, and race. Id. Other reasons are industry specific and include lack of performance information, bank consolidation, and financial innovation (credit scoring). Id.

4 See David G. Blanchflower et al., Discrimination in the Small Business Credit Market, National Bureau of Economic Research, Working Paper Series, 3 (Dec.1998), available at http://www.nber.org/papers/w6840 (showing that when applying for small business loans, black-owned firms are statistically discriminated against when compared to white-owned firms); see also Ken Cavalluzzo \& John Wolken, Small Business Loan Turndowns, Personal Wealth and Discrimination, 5 (July 2002), available at $\mathrm{http} / / / \mathrm{www} . f e d e r a l r e s e r v e . g o v / p u b s / f e d s / 2002 / 200235 / 200235$ pap.pdf (showing that differences in personal wealth do little to explain why minority-owned firms are denied credit at a higher rate than white-owned firms and that discrimination is a prevalent reason for loan denial); see also Ken Cavalluzo et al., Competition, Small Business Financing, and Discrimination: Evidence From a New Survey, 23 (Feb. 1999), available at http://www.federalreserve.gov/pubs/feds/ 1999/199925/199925pap.pdf (showing that minority-owned firms are discriminated against more heavily in markets where there is less bank competition).

5 Minorities are expected to represent ninety percent of population growth until 2050. U.S. Department of Commerce Minority Business Development Agency \& U.S. Census Bureau, Dynamic Diversity: Projected Changes in U.S. Race and Ethnic Composition 1995 to 2050, 5, (Dec. 1999), available at http://www.mbda.gov/documents/unpubtext.pdf. More importantly, minority-owned firms account for fifty six percent of workforce growth and are expected to account for between sixty four and seventy percent in the next twenty years. Milken Institute \& U.S. Department of Commerce Minority Business Development Agency, The Minority Business Challenge: Democratizing Capital for Emerging Domestic Markets, 5 (Sept. 25, 2000), available at http://www.mbda.gov/documents/democratizing.pdf. 
The next section will provide background information as to the origins and mechanics of securitization. Section III will recommend several changes that will improve the secondary market for small business loans. Finally, section IV will conclude.

\section{BACKGROUND}

This section will discuss (A) the history of securitization, (B) the intricacies of a securitization transaction, and (C) why firms securitize their assets.

\section{A. The History of Securitization}

The success of securitization has been primarily driven by the United States Federal Government. ${ }^{6}$ In encouraging home ownership, Congress created government-owned and government-sponsored entities to create a secondary market for residential mortgages. ${ }^{7}$ The first of these entities is the Federal National Mortgage Association, which was created in 1938 to purchase federally-insured home mortgages. ${ }^{8}$ The Federal National Mortgage Association became known as Fannie Mae. In 1968, Fannie Mae was split into two separate entities, the first of which retained the name Fannie Mae and was a privately-owned government-sponsored entity. ${ }^{9}$ The second entity is the Government National Mortgage Association, better known as Ginnie Mae, and is a government-owned entity. ${ }^{10}$ Both Fannie Mae and Ginnie Mae were created to purchase and sell federally-insured mortgages. Finally, in 1971, Congress created the Federal Home Loan Mortgage Corporation or Freddie Mac in order to improve the secondary market for conventional home mortgages. ${ }^{11}$ Like Fannie Mae, Freddie Mac is a privatelyowned government-sponsored entity. While creating Freddie Mac, Congress also augmented the authority of Fannie Mae enabling it to purchase conventional and variable-rate loans. ${ }^{12}$

6 Joseph C. Shenker \& Anthony J. Colletta, Asset Securitization: Evolution, Current Issues and New Frontiers, 69 TEX. L. Rev. 1369, 1383 (1991); Stephen J. Cosentino, Swimming in New WatersBank Participation in Securitized Loan Pools, 65 UMKC L. Rev. 543, 544 (1997); Amy C. Bushaw, Small Business Loan Pools: Testing the Waters, 2 J. SMALl \& EMERgING Bus. L. 197, 216-17 (1998).

7 Peter F. Culver, The Dawning of Securitization, 8-APR PROB. \& PROP. 34, 36 (1994); The Committee on Bankruptcy and Corporate Reorganization of the Association of the Bar of the City of New York, Structured Financing Techniques, 50 Bus. LAw. 527, 537 (1995) (hereinafter "Structured Financing Techniques"); Bushaw, supra note 6, at 217.

8 Shenker \& Colletta, supra note 6, at 1384.

9 Bushaw, supra note 6, at 217.

$10 \quad$ Id.

11 In response to a near crisis in the housing industry, Congress passed the Emergency Home Finance Act of 1970 creating Freddie Mac. Shenker \& Colletta, supra note 6, at 1384. Freddie Mac was created for the purpose of improving the secondary market in conventional residential mortgages. Bushaw, supra note 6, at 217.

12 Shenker \& Colletta, supra note 6, at 1384. 
In 1970, Ginnie Mae issued the first securities backed by pools of home mortgages. ${ }^{13}$ The securities issued by Ginnie Mae were backed by pools of FHA-insured or VA-guaranteed residential mortgages. ${ }^{14}$ Investors in these securities purchased pass-through certificates entitling them to the borrowers' principal and interest payments as they came due. ${ }^{15}$ Ginnie Mae served as the guarantor of full and timely payment of principal and interest. $^{16}$

Fannie Mae and Freddie Mac soon issued securities of their own. ${ }^{17}$ Unlike Ginnie Mae's securities, these securities did not carry with them an explicit government guarantee. ${ }^{18}$ However, participants in the market for these securities regarded these securities as if though they carried an implicit government guarantee. ${ }^{19}$

Fannie Mae, Ginnie Mae, and Freddie Mac are still responsible for most mortgage securitization transactions today. ${ }^{20}$ By 1994, over \$1 trillion in mortgage backed securities were outstanding. ${ }^{21}$ Mortgages are the most widely securitized financial assets. ${ }^{22}$

In the 1980s, more complex payment structures began to emerge creating a wider investment market for mortgage-backed securities. ${ }^{23}$ Beginning in 1983, Freddie Mac issued Collateralized Mortgage Obligations known as CMOs. $^{24}$ These CMOs altered the traditional pay-through structure of mortgage-backed securities by creating tranches with different payment structures in order to meet the needs of different investors. ${ }^{25}$ The Tax Reform Act of 1986 allowed for pass-through tax treatment for entities issuing multiple classes or tranches of securities by creating Real Estate Mortgage Investment Conduits, or REMICs. ${ }^{26}$ These REMICs allowed for entities issuing securities similar to CMOs to not be taxed at the entity level. ${ }^{27} \mathrm{Be}-$ cause loan originators soon began originating loans fashioned for securiti-

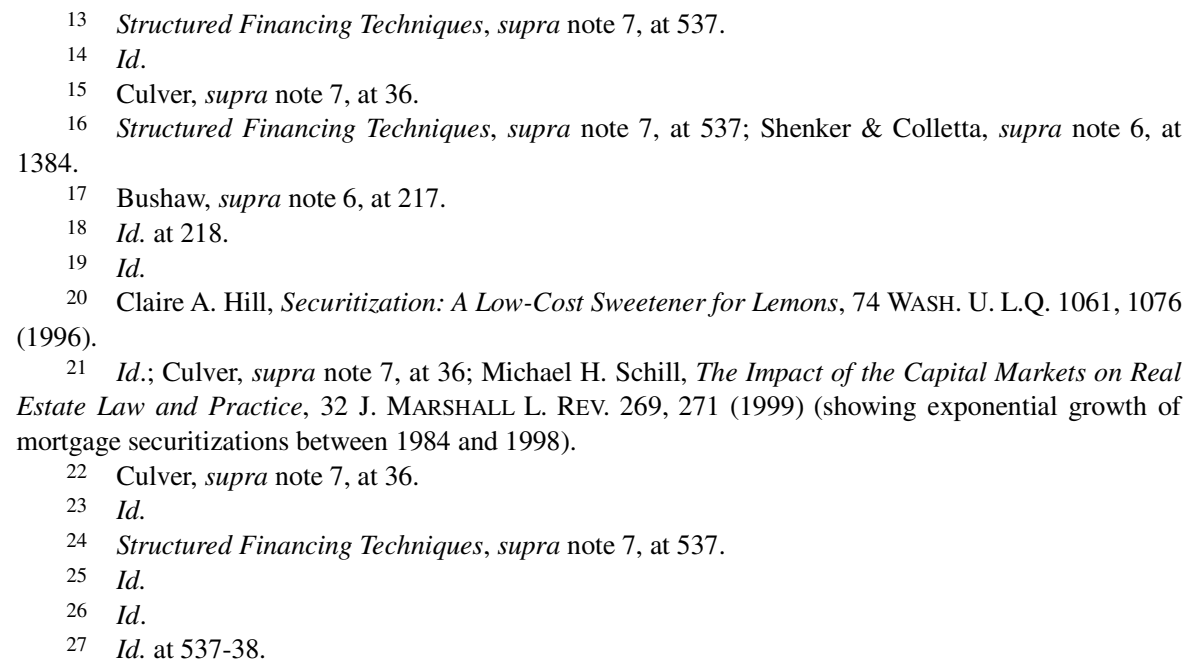


zation, uniform legal documentation and underwriting standards for conventional residential mortgages were introduced by the federal agencies that participated in securitization. ${ }^{28}$ This improved the prospects of securitization since it was now easier to predict payment patterns and the overall credit risk of the mortgages being securitized.

The private sector entered the secondary mortgage market when California Federal Savings and Loan issued the first publicly rated mortgagebacked security in $1975 .^{29}$ In 1977, Bank of America issued the first publicly rated security backed by conventional mortgages. ${ }^{30}$ Eventually, mortgage bankers, home builders, investment banks, and insurance companies began issuing mortgage backed securities of their own. ${ }^{31}$

Gaining from the experiences of the secondary mortgage market, other types of financial assets were soon being securitized. In 1975, Sperry Corporation began securitizing operating leases for computer equipment. This transaction received a higher credit rating than Sperry's own rating. The securitization of other types of leases soon ensued, including the securitization of automobile, equipment, and aircraft leases.

Also, in 1985, automobile loans were first securitized by Marine Midland Bank and Valley National Bank. ${ }^{32}$ Soon after, larger issuers began securitizing automobile loans, including General Motors Acceptance Corporation, Chrysler Financial Corporation, and Nissan Motors Acceptance Corp.

By 1987, Bank of America and Republic Bank of Delaware offered securities backed by credit card receivables. ${ }^{34}$ As early as 1994, securitizations of credit card receivables were increasing while mortgage securitization began to significantly decline.

The Federal Government also remained active in the securitization of financial assets other than residential mortgages. The Federal Government has participated in the securitization of student loans through the Student Loan Marketing Association, also known as Sallie Mae, and agricultural loans through the Federal Agricultural Mortgage Corporation or Farmer

Shenker \& Colletta, supra note 6, at 1385

Structured Financing Techniques, supra note 7, at 537.

Id.

31 Id.

32 Id. at 538. Because of their predictable payment patterns and standardized terms, automobile loans have become popular subjects of securitization transactions. Cosentino, supra note 6, at 546.

33 Structured Financing Techniques, supra note 7, at 538.

34 Id. Like automobile loans, credit card receivables have become popular targets of securitization because of their predictable payment patterns and standardized terms. Cosentino, supra note 6, at 546. 
Mac. ${ }^{35}$ The Resolution Trust Corporation soon began to securitize commercial mortgages obtained from insolvent thrifts. ${ }^{36}$

Recent years have seen the securitization of assets that are very different from loan and lease receivables. These assets include tax lien receivables and taxicab medallions. ${ }^{37}$ Perhaps the most unique securitization is that of royalties to David Bowie songs. ${ }^{38}$ In 1997, David Bowie raised \$55 million by issuing securities backed by royalties on his first twenty five albums.

The spread of securitization to financial assets other than residential mortgages has resulted in a constant evolution of securitization transactions to more complex structures. Changes in regulatory treatment have resulted in the creation of various types of credit enhancement, other than implicit and explicit government guarantees, including cash collateral accounts, spread accounts, and subordinated interests. ${ }^{40}$ Entities known as master trust vehicles or securitization conduits have also evolved from different types of securitization transactions. ${ }^{41}$ These entities permit an issuer to continuously purchase financial assets and to issue new securities against the assets without the need to create a new entity for each purchase. ${ }^{42}$ In addition, multi-originator conduits which allow different originators to sell their assets to one entity which then issues securities against the assets have also come into existence as a result of the various different types of securitizations. $^{43}$

Despite the spread of securitization across many different types of financial assets, the securitization of small business loans has remained relatively unsuccessful. While some success has been seen in the area of Small Business Administration loans, conventional small business loans have rarely been securitized. ${ }^{44}$

Securitization of SBA loans has had success for several reasons. First, the loans are guaranteed by the Small Business Administration and thus,

Bushaw, supra note 6, at 217.

Id.

Id. at 219.

Id.

39 Adam Grant, Ziggy Stardust Reborn: A Proposed Modification of the Bowie Bond, 22 CARDOZO L. REV. 1291, 1291-92 (2001).

$40 \quad$ Structured Financing Techniques, supra note 7, at 539.

41 Id.

42 Id.

43 Id.

44 Kenneth Temkin \& Roger C. Kormendi, An Exploration of a Secondary Market for Small Business Loans, SBA Office of Advocacy, 13 (2003), available at http://www.sba.gov/advo/re search/rs227_tot.pdf. Between 1994 and 2000, there were only 59 securitization transactions that used unguaranteed portions of SBA loans or conventional small business loans. Id. These transactions only included $\$ 6.9$ billion of loans. Id. To the contrary, 43\% of SBA loans were securitized between 1995 and 2000. Id. at 14 . 
carry no credit or default risk. ${ }^{45}$ Second, the loans have uniform underwriting standards and documentation, making their payment patterns easy to predict. ${ }^{46}$ Even the unguaranteed portions of SBA loans have been successful in securitization transactions because they too benefit from uniform documentation and underwriting standards. ${ }^{47}$

Conventional small business loans are traditionally decided using what is known as relationship underwriting. ${ }^{48}$ As a result, conventional small business loans lack the homogeneity of other types of financial assets that have had success in securitization transactions. ${ }^{49}$ Conventional small business loans do not possess predictable payment patterns and thus, their credit or default risk is difficult to ascertain. ${ }^{50}$ Several solutions could improve the outlook of conventional small business loan securitizations. These solutions begin with the creation of a government-sponsored entity similar to Freddie Mac in order to begin creating an efficient secondary market for conventional small business loans. ${ }^{51}$ The creation of such a market will impose uniform documentation and underwriting standards on originators of conventional small business loans wishing to securitize their loans. ${ }^{52}$ This would result in moving away from relationship underwriting as a method of making loan decisions to credit scoring models that are already available in the marketplace. ${ }^{53}$ By doing so, it now would become easier to predict the payment patterns of conventional small business loans. ${ }^{54}$ Moreover, the creation of a government-sponsored entity will enhance the confidence investors have in securities backed by conventional small business loans. ${ }^{55}$

$45 \quad I d$.

$46 \quad I d$.

47 Id. The unguaranteed portions of SBA loans are also developing a secondary market with about $8.5 \%$ of the total unguaranteed volume being securitized between 1995 and 2000. Id .

$48 I d$. at 5 . There has been a trend towards automated credit scoring models as more originators are beginning to use them to underwrite small business loans. Id. at 9 .

$49 I d$. at 10. For the most part, lenders decide small business loan applications based on the information gained through the borrower's banking relationship, their business model, and management expertise. Id.

$50 \quad I d$. at 5.

$51 \quad I d$. at 28.

52 Id.

53 Just as government involvement in the securitization of residential mortgages resulted in uniform underwriting standards, the securitization of conventional small business loans by government sponsored enterprises will result in uniform underwriting standards. Credit scoring models are readily available for small business loans and the current trend is that originators are adopting these technologies to make decisions on small business loan applications.

54 Credit scoring "models provide for an objective and easily analyzed assessment of the risks associated with a given loan." Id. at 10 .

55 In order to securitize small business loans, there must be investors willing to purchase securities backed by them. Bushaw, supra note 6 , at 226 . Interest depends on the risk and return characteristics of securities backed by small business loans. Id. Securities issued by Government-sponsored entities are "generally regarded to carry an implicit guarantee." Id. at 252. This implicit guarantee in- 
Another solution is to create credit enhancement mechanisms where the federal government guarantees a portion of the underlying small business loans in the securitization transactions. ${ }^{56}$ This would decrease or eliminate the credit risk associated with the small business loans. ${ }^{57}$ This would also increase the confidence investors have in securities backed by conventional small business loans. ${ }^{58}$

\section{B. The Intricacies of a Securitization Transaction}

In order to understand what needs to be done to improve the prospects of small business loan securitizations, it is important to understand the intricacies of a securitization transaction.

Securitization is the sale of securities backed by an income-producing asset or pool of assets. ${ }^{59}$ Firms employ securitization as a form of transforming illiquid financial assets into liquid securities which in turn become cash. $^{60}$ The goal of a securitization transaction is to package cash flows from income-producing assets into a security that is of high quality and saleable on the capital markets. ${ }^{61}$ A securitization transaction is structured

creases confidence in securities backed by small business loans since the likelihood of default on those securities is minimal.

56 Temkin \& Kormendi, supra note 44 , at 28

57 All forms of credit enhancement serve the purpose of decreasing the risk inherent in securitized assets. See discussion infra Part II.B.1. In the case of a credit enhancement provided by the government, credit risk is entirely eliminated on that portion of assets which are guaranteed.

58 Bushaw, supra note 6 , at 226. The willingness of investors to purchases securities backed by small business loans hinges on the risk and return characteristics of the securities. Id. Securities which are backed by government guaranteed assets have significantly reduced the credit risk associated with theses assets and, naturally, investors' confidence in the securities is increased.

59 Shenker \& Colletta, supra note 6, at 1374.

60 Id. at 1373; see also Lynn A. Soukup, When Assets Become Securities: The ABC's of Asset Securitization, 6-DEC BUS. L. TODAY 20, 20 (1996) ("Asset securitization transactions benefit issuers by providing liquidity or working capital at interest rates that are often significantly more favorable than what the creditworthiness of the owner of the assets [the originator] would support in a more conventional financing."); see also Steven L. Schwarcz, The Alchemy of Asset Securitization, 1 Stan. J.L. Bus. \& Fin. 133, 136 (1994) ("Securitization is most valuable when the cost of funds, reflected in the interest rate that is necessary to entice investors to purchase the SPV's securities, is less than the cost of the originator's other, direct sources of funds.").

61 Hill, supra note 20, at 1073-74. High quality of a security hinges on the assurance of repayment and is demonstrated through high ratings, for the most part. Id. at 1073 In addition, the security could carry with it other assurances of repayment such as third party guarantees, over collateralization, and liquidity facilities. $I d$. These are known as credit enhancements. $I d$. The ability to securitize highly rated assets is especially enticing to firms that carry a low rating. Id. Securitization enables these firms to issue securities based on highly rated assets or receivables and "[leave] behind the firm and its undesirable attributes." Id. The firms can attach third party appraisals (ratings), and credit enhancements to lower their cost of funds through the securitization because a security that is saleable in the capital markets normally carries with it the lowest cost of funds. Id. at 1074.

To be saleable on the capital markets, securities must have characteristics that permit liquidity.... They must be comparatively cheap and easy to appraise, buy, hold, and sell.... Purchases and sales also must be comparatively easy: the security's general features, such as payment 
to minimize or shift risks inherent in the underlying assets and to ensure that securities backed by these assets are readily marketable. ${ }^{62}$ Assets with standardized terms such as uniform underwriting and predictable losses that can be demonstrated through actuarial analysis are suitable for securitization. ${ }^{63}$ For the most part, investors in asset-backed securities make judgments as to the quality of the security and the required rate of return based on the ratings assigned to the security by the major rating agencies and other credit enhancements structured into the securitization transaction. ${ }^{64}$ Thus, it is important to focus on how the structure of the securitization transaction, including the selection of assets, method of transfer, type of security issued, and any safeguards attached to the transaction, will affect the ratings given to the securities by the major rating agencies.

In a securitization transaction, an originator transfers financial assets, such as loans, leases, and receivables, to an entity sometimes known as a Special Purpose Vehicle, which issues securities to investors and uses the proceeds from the sale of these securities to pay the originator for the assets. ${ }^{65}$ The Special Purpose Vehicle issues claims or securities against the

terms and denominations, must be of more than idiosyncratic appeal, and the transaction costs of purchasing and selling the security must be comparatively low.

Id.; see also Schwarcz, supra note 60, at 137 ("A securitization transaction can provide obvious cost savings by permitting an originator whose debt securities are rated less than investment grade or whose securities are unrated to obtain funding through an SPV whose debt securities have an investment grade rating.").

62 Shenker \& Colletta, supra note 6, at 1374-75.

63 Id. at 1377

64 Hill, supra note 20, at 1072. Rating agencies play an integral role in the determination of quality of securities arising out of a securitization transaction.

Pool securities are almost always passive investments. Many investors make no investigation or appraisal of the securities or the underlying collateral, the receivable, beyond simply reviewing the offering documents. Rather, ratings and a third party guarantee, (and perhaps overcollateralization) often substitute for investor appraisal of the receivables. Investors need consider Id. at 1073; only the terms of the pool securities, the rating, and the stature of the guarantor.

Investors in asset-backed securities generally receive the benefit of a review by one or more nationally recognized rating agencies, such as Standard \& Poor's, Moody's, Fitch, and Duff \& Phelps. The agencies focus on the origination and servicing of the assets being securitized and the structure of the securitization ....

See Soukup, supra note 60, at 20.

The interest rate necessary to entice investors to purchase the SPV's securities is often a function of the "rating" that the SPV's debt securities receive. Such ratings are determined by various independent private companies that have gained widespread investor acceptance as "rating agencies." Given that most investors, except certain institutional investors in private placement transactions (discussed below), have neither the time nor the resources to fully investigate the financial condition of the companies in which they invest, these ratings take on special significance. Investors rely on the assigned ratings to determine the minimum return that they will accept on a given investment.

See Schwarcz, supra note 60, at 136.

65 Culver, supra note 7, at 34; see also Yuliya A. Dvorak, Transplanting Asset Securitization: Is the Grass Green Enough on the Other Side?, 38 Hous. L. REV. 541, 546 (2001). In their simplest form, 
pool of assets in the form of debt or equity. ${ }^{66}$ The asset or pool of assets that are securitized are financial or income-producing assets, meaning that they generate cash flows from which payments are made to the holders of the debt or equity instruments that are issued. ${ }^{67}$

In making a securitization transaction attractive to investors in the capital markets, the transaction should be structured to (1) minimize asset risks by carefully selecting and enhancing the pool of assets and (2) minimize entity risks by creating a bankruptcy remote Special Purpose Vehicle. In the upcoming sub-sections, the analysis will focus on how the handling of asset and entity risks affects the rating determinations of the major rating agencies which are very influential in ascertaining the quality and marketability of the securities issued in a securitization transaction.

\section{Selecting and Enhancing the Pool of Assets}

The assets involved in a securitization transaction are normally illiquid financial assets that produce a cash flow from which the holders of the securities issued in the transaction can be paid. ${ }^{68}$ The assets typically represent rights to future monies or payments at future dates and are referred to as "receivables." as the source of payments on the asset backed security and the payment performance of the assets "must be susceptible to evaluation.," As stated above, assets most suitable for securitization have standardized terms, expected losses that can be predicted, ${ }^{71}$ and have uniform underwriting standards and servicing procedures. ${ }^{72}$ Receivables with a higher rate of default may still be securitized as long as the rate of default can be predicted. $^{73}$ Normally, the assets, by themselves, are not saleable in the capital markets

\footnotetext{
asset securitizations involve a sale of financial assets by an originator to a separate corporation or trust, usually called an SPV. The SPV raises the purchase price by selling debt or equity interests. "This series of transactions leaves the investors with claims against the SPV, the SPV with the assets transferred by the originator, and the originator with the proceeds of the transaction." Id.

66 Shenker \& Colletta, supra note 6, at 1378.

67 Robert R. Veach, Jr., Securitization of Assets, 30 Mar. BuLL. BuS. L. SEC. ST. B. TEX. 23, 24-25 (1993); see also Shenker \& Colletta, supra note 6, at 1376-77, 80; see also Dvorak, supra note 65, at 546-47 (assets being securitized can be of various natures, including oil and gas, lease, auto loan or credit receivables, commercial mortgage loans, state lottery winnings, litigation settlement payments, and royalties).

68 Shenker \& Colletta, supra note 6, at 1376.

69 Schwarcz, supra note 60, at 135; see also Hill, supra note 20, at 1067.

70 Soukup, supra note 60, at 21.

71 Id. ("With a pool of consumer receivables, a statistical analysis of the historical performance of similar consumer receivables is used to evaluate payment, delinquency, default and recovery rates. A pool composed of fewer assets that are not readily subject to statistical analysis-such as a pool of commercial mortgage loans-generally will require underwriting of the individual assets, and the rating agencies usually have specific criteria for the assets to be included in the pool.").

72 Shenker \& Colletta, supra note 6, at 1377.

73 Schwarcz, supra note 60, at 135.
} 
because they require costly monitoring and appraisal, and their payment terms may be unpredictable.

"Asset risks" are those risks which are inherent in the receivables, ${ }^{75}$ "such as the possibility that account debtors may fail to pay on time and in full." 76 Once all the asset risks have been analyzed and projected, the types and amounts of credit enhancement for the asset-backed securities are established. $^{77}$

A securitization transaction is structured to minimize the effects of these risks through the use of credit enhancements designed to reduce risk and improve the marketability of the securities issued. ${ }^{78}$ Through the use of the various credit enhancement mechanisms, the Special Purpose Vehicles are able to receive a higher credit rating than the originator, allowing it to secure financing at a lower cost. ${ }^{79}$ Credit enhancement serves two broad purposes: first, it bridges the gap between the limitations of the issuer and the demands of the investor, ${ }^{80}$ and second, it provides an analytical service

74 Hill, supra note 20, at 1074; see also Schwarcz, supra note 60, at 144 (quoting PETER H. WEIL, FACTORING IN ASSET BASEd FinANCing: A TRANSACTIONAL Guide § 27.01(1) (Matthew Bender ed., 1985)) (the sale of the individual receivables is known as factoring).

75 The most important risks in an asset-backed security include credit risk, liquidity risk, refinancing risk, reinvestment risk, administration performance risk, currency and interest rate risk, swap counterparty risk, and credit risk on mortgage indemnity guarantee provider. For a detailed explanation of each individual risk, see Fredrik Månsson, Credit Enhancement, in THE GloBAL AsSET BACKed SECURITIES MARKET 169, 169-71 (Charles Stone et al. eds., 1993).

76 Dvorak, supra note 64, at 550 (By contrast, "Entity Risks" are the risks inherent in the originator. More specifically, entity risk is the risk that an originator's potential insolvency will affect the payment of cash flows to investors.). Entity risks will be addressed in the next section in the analysis of the choice of entity.

77 Soukup, supra note 60 , at 21

78 Shenker \& Colletta, supra note 6, at 1379 (securitization transaction is structured to reduce risks inherent in the underlying assets, and to permit, to the greatest extent possible, the ready resale of the securities issued); see also Hill, supra note 20, at 1072 (the transaction may include a guarantee of repayment by a highly rated third party guarantor, overcollateralization, and liquidity facilities-if the repayment patterns of the underlying receivables are less predictable); Dvorak, supra note 65, at 560 ("Credit enhancement, among other things, allows the SPV to address the default risk through the use of guarantees, letters of credit, irrevocable credit lines, third-party insurance, or over-collateralization."); and Christine A. Pavel, Securitization: The Analysis and Development of the LoanBASED/ASSET-BACKED SECURITIES MARKETS 17 (1989) ("The riskiness of an asset-backed security is the main determinant of its price. The riskier the security, the lower the price, and therefore the yield. . . . Several options to decrease the riskiness of an issue are available to a securities issuer, however.").

79 Dvorak, supra note 65 , at 560.

80 In transactions as complex as public asset-backed securities, the credit quality and cash flow characteristics of a given asset pool will rarely match exactly the investors' objectives. . . . Credit enhancement is a tool that helps bridge this gap-enabling issues to be structured with the cash flow timing and certainty that investors require, while retaining the flexibility that issuers need to meet accounting, regulatory, and funding goals.

Russell B. Brewer II \& Linda S. Iseley, Credit Enhancement for Asset-Backed Transactions, in THE HANDBOOK OF ASSET-BACKED SECURITIES 127, 128-29 (Jess Lederman ed., 1990). 
for investors. ${ }^{81}$ The different types of credit enhancements are either internal $^{82}$ or external. ${ }^{83}$

Internal credit enhancements include over-collateralization, excess spread accounts, and senior-subordinate structure. ${ }^{84}$ Over-collateralization is where the face value of the assets transferred is greater than the face value of the securities to be issued in order to allow for probable losses. ${ }^{85}$ For example, assume that a pool of loans has a face value of $\$ 10$ million while the securities being issued against the pool only has a face value of $\$ 9$ million. The securities are over-collateralized by $\$ 1$ million. ${ }^{86}$ As a result, the excess $\$ 1$ million acts as a loan loss reserve providing a credit enhancement to investors. ${ }^{87}$

The second type of internal credit enhancement is an "excess spread account," where the excess cash flow derived from the pool of assets, because of the difference between the interest rate of the underlying pool and the interest rate paid to investors, is held in an account and used as a loan loss reserve. ${ }^{88}$ For example the average interest rate for a pool of assets may be nine percent while the average interest rate of the securities issued is eight percent. The excess of one percent is held in an account and used as a loan loss reserve, providing a credit enhancement for investors. ${ }^{89}$

The third internal credit enhancement, a senior-subordinate structure, is present where the SPV issues several classes or tranches of securities against the pool of assets. For example, the issuance could include senior and subordinated debt. "Through this type of structure, the subordinated tranche bears the default risk on the underlying loans, and only if the subordinated tranche and other forms of credit are insufficient to bear the loss does the investment grade carry any risk." ${ }^{, 00}$ The subordinated tranche acts as a loan loss reserve, and the size of the reserve depends on the risk of the

81 Because a credit enhancer is putting its capital at risk against the total financing, it does an indepth analysis of the performance to be expected from the security and investors benefit from this analysis. Id. at 129 .

82 Temkin \& Kormendi, supra note 44, at 15 (internal credit enhancements are provided by the underlying assets themselves); see also Bushaw, supra note 6, at 224 ("The pool of assets itself can be structured to reduce the risk that cash flow from the assets will not be available to pay the securities when due.").

83 Temkin \& Kormendi, supra note 44, at 15 ("External credit enhancements are provided by third parties who offer financial guaranty insurance issued by monoline insurers."); see also Bushaw, supra note 6, at 224 ("External methods of credit support may be used to enhance the credit ratings of the securities issued by the SPV.").

84 Id.; see also Temkin \& Kormendi, supra note 44, at 15.

85 Bushaw, supra note 6, at 224.

86 Temkin \& Kormendi, supra note 44 , at 15-16.

87 Id. at 16.

88 Bushaw, supra note 6, at 224; Temkin \& Kormendi, supra note 44, at 16.

89 Bushaw, supra note 6, at 224.

$90 \quad$ Id. 
underlying assets. ${ }^{91}$ The subordinated tranche functions as a credit enhancement, allowing the senior tranche to receive a higher rating.

External credit enhancements include recourse to the originator, thirdparty recourse, or other forms of credit support. ${ }^{92}$ External credit enhancement "can take the form of an insurance policy issued by a financial guarantee insurance company, ${ }^{93}$ a letter of credit issued by a bank, ${ }^{94}$ a corporate guarantee, ${ }^{95}$ or a reserve account funded by a third party. ${ }^{96,97}$ The simplest form of credit enhancement is direct recourse to the originator in the form of an unsecured obligation. ${ }^{98}$ Third party guarantors, such as insurance companies, structure securitization transactions so that they incur no losses by requiring that the expected loss from the underlying assets is covered through first loss protection in the form of over collateralization and other

91 The higher the risk that is inherent in the underlying assets, the larger the size of the subordinated tranche needs to be so that the rating of the senior tranche can be suitable to investors. Temkin \& Kormendi, supra note 44, at 15.

92 Recourse to the originator or a third-party can be in the form of a letter of credit or other contractual relationships such as guarantees. Other forms of external credit support include default insurance. Bushaw, supra note 6 , at 224-25.

93 See Månsson, supra note 75, at 171 (“An insurance company will enter into an insurance contract with the issuer under which it agrees to indemnify the issuer in respect of credit losses originating from the underlying pool of financial assets."); see also Lina Hsu \& Cyrus Mohebbi, Credit Enhancement in ABS Structures, in ASSET-BACKED SECURITIES 277, 278-79 (Anand K. Bhattacharya \& Frank J. Fabozzi eds., 1996) (The most common technique of external credit enhancement is provided by monoline insurance companies such as Municipal Bond Investors Assurance, Financial Guaranty Insurance Company, and others. These entities insure investment grade rated cash flows for an up front fee determined by the desired rating level.).

94 See Månsson, supra note 75, at 172 ("One solution to both the credit risk and the liquidity risk is to have a bank or an insurance company with the appropriate rating to issue a guarantee, which covers the SPV against the credit and liquidity risk in the portfolio."); see also Hsu \& Mohebbi, supra note 93, at 279 (A letter of credit is an insurance policy issued by a financial institution that carries a credit rating higher than the security being guaranteed. Under the letter of credit, the financial institution is obligated to reimburse losses up to a specified amount.).

95 Hsu \& Mohebbi, supra note 92, at 279. (“[A] corporate guarantee protects bond holders from losses due to default, bankruptcy, fraud, and standard and special hazards of the underlying assets, with full recourse to the guarantor. The rating of the security is directly affected by any upgrade or downgrade of the guarantor as the highest rating an insured security can obtain is the rating of the guarantor.").

96 Id. at 279-80 (A "Cash Control Account" is a loan to the issuing trust with the proceeds reinvested in some short-term eligible investments and repaid through excess spread from the transaction.).

This method of credit and liquidity protection has been used in, for instance, securitizations of credit card receivables in the US. A substantial amount of cash, maybe 6-10 percent of the total issue size, is placed in an escrow account at the beginning of the transaction. The cash is used to pay credit losses in the asset portfolio and to take care of temporary liquidity problems.

See Månsson, supra note 75, at 172.

97 Len Blum \& Chris DiAngelo, Structuring Efficient Asset-Backed Transactions, in IssUER PERSPECTIVES ON SECURITIZATION 17, 30 (Frank J. Fabozzi ed., 1998).

98 While it is the simplest form of enhancement, it is the most difficult for an investor to evaluate because the investor must evaluate the strengths and weaknesses of the issuer and must consider any correlation between the risks associated with the pool of assets and the issuer. Brewer \& Iseley, supra note 80 , at 131 . 
credit enhancers before it is covered by their guarantee. Thus, financial guarantees are typically considered second loss protection and only come into effect if the first loss protection fails to cover the losses stemming from the underlying assets. ${ }^{99}$

In order to make securities issued by a Special Purpose Vehicle marketable at an interest rate attractive to investors, investors must be shielded from asset risks such as liquidity and credit risks through the use of credit enhancement. $^{100}$ The amount of credit enhancement used in a particular transaction is a direct function of the risk of the underlying assets, and the costs associated with different types of credit enhancement. ${ }^{101}$ Many securitizations are complex and include a combination of more than one type of credit enhancement. ${ }^{102}$ In the case of monoline insurance, the guarantor will not insure the security unless it is rated at an investment-grade level, meaning that other types of credit enhancements are typically needed in addition to monoline insurance. ${ }^{103}$

\section{Striving for a Bankruptcy Proof Special Purpose Vehicle}

Entity risks are those risks associated with the economic prospects of the originator and the issuer, such as their general credit rating and the possibility that either will end up in bankruptcy. ${ }^{104}$ Investors in asset backed securities expect to have certain asset risks, but do not expect to incur risks related to the insolvency of the originators in a securitization transaction. For that reason, rating agencies require that Special Purpose Vehicles are bankruptcy remote in order for the transaction to receive a rating that makes issued securities saleable on the capital markets. Bankruptcy remoteness is generally accomplished by limiting the scope of the SPV's business, restricting the liabilities the SPV may incur, preserving the separate identity of the SPV, and ensuring that the key parties to a transaction not file for bankruptcy. ${ }^{105}$ In order to minimize or eliminate entity risks, an ideal securitization attempts to ensure that the asset or pool of assets are segregated

99 Mahesh K. Kotecha, The Role of Financial Guarantees in Asset-Backed Securities, in ISSUER PERSPECTIVES ON SECURITIZATION 93, 103 (Frank J. Fabozzi ed., 1998).

100 Culver, supra note 7, at 35 .

101 Temkin \& Kormendi, supra note 44, at 16; see also Pavel, supra note 77, at 32 ("Riskier deals require a higher level of credit enhancement."); see also Blum \& DiAngelo, supra note 97, at 255-56 (credit enhancement decisions are based on the costs associated with the various forms of credit enhancement).

102 For instance, it is possible for an asset backed security to have a senior-subordinate structure, over-collateralization, and a spread account, all forms of internal credit enhancement. The issuer may also decide to use an external credit enhancement as well. Temkin \& Kormendi, supra note 44, at 16.

103 Blum \& DiAngelo, supra note 97, at 253.

104 Dvorak, supra note 65, at 550.

105 Stephen H. Case, I Thought I Put That Where You Couldn't Reach It: Bankruptcy-Remote Entities, Special Purpose Vehicles and Other Securitization Issues, 853 PRAC. LAW. INST. COM. L. \& PRAC. COURSE HANDBOOK SERIES 53, 68 (2003). 
from the originator's other assets and that the Special Purpose Vehicle is created in a manner that significantly limits the likelihood of insolvency. ${ }^{106}$ Transferring the assets to a Special Purpose Vehicle that is restricted to owning and servicing the assets minimizes the risks associated with the possible insolvency of the originator and the Special Purpose Vehicle. ${ }^{107}$ Securitization transactions should not strive to be bankruptcy remote, but to be bankruptcy proof. While avoiding consolidation of assets and ensuring that the assets are transferred as a true sale can achieve bankruptcy remoteness, constructing the Special Purpose Vehicle so that it cannot engage in activities that expose it to undue risk of its own would make the securitization transaction near bankruptcy proof status. ${ }^{108}$

In order to make a securitization transaction of high quality and saleable in the capital markets, entity risks must be minimized. This section addresses how these risks can be minimized within the structure of the transaction. In order to minimize the entity risks associated with a securitization transaction, an SPV must be (1) bankruptcy remote, or protected from the potential insolvency of the originator, and then (2) bankruptcy proof, or protected from the potential insolvency of the SPV, itself.

a) Bankruptcy Remoteness: True Sale, Substantive Consolidation, and Fraudulent Conveyance. There are three ways that the assets can become exposed to bankruptcy risk associated with the originator. First, the transfer from the originator to the Special Purpose Vehicle is not treated as a "true sale" but as a pledge of collateral, and the assets become part of the bankruptcy estate. ${ }^{109}$ Second, the assets may be substantively consolidated with those of the originator or another entity in a bankruptcy proceeding involving the originator or other entity. ${ }^{110}$ Finally, the transfer can be treated as a fraudulent conveyance. ${ }^{111}$ These three exposures to bankruptcy risk should be addressed in order to ensure that a securitization is bankruptcy remote. As discussed above, rating agencies require Special Purpose Vehicles to be bankruptcy remote in order to ensure a rating making securities issued by such entities saleable on the capital markets. In order to achieve bankruptcy remoteness, (i) the transaction must avoid being recharacterized as a secured loan; (ii) the assets and liabilities of the SPV must avoid being consolidated with the originator; and (iii) the transfer must not constitute a fraudulent conveyance.

\footnotetext{
106 Shenker \& Colletta, supra note 6, at 1377; see also Soukup, supra note 60, at 21.

107 Robert Dean Ellis, Securitization Vehicles, Fiduciary Duties, and Bondholder's Rights, 24 J. CORP. L. 295, 305-06 (1999); see also Shenker \& Colletta, supra note 6, at 1377.

108 Blum \& DiAngelo, supra note 97, at 23.

109 Shenker \& Colletta, supra note 6, at 1377 n.35; see also Ellis, supra note 107, at 305.

110 Shenker \& Colletta, supra note 6, at 1377 n.35.

111 Id.
} 
i. True Sale Characterization. A bankruptcy court may find that the transfer of assets was not a "true sale," but a mere pledge for a secured loan and recharacterize the securitization transaction as such. ${ }^{112}$ This would expose the assets or pool of assets to risks associated with the potential insolvency of the originator. In order to structure a securitization as bankruptcy remote, it is important to ensure that the transaction is a true sale, making the securities issued against the pool of assets more attractive to investors and saleable in the capital markets. Moreover, if a transaction is characterized as a true sale, it is unlikely that the transaction will be considered a fraudulent conveyance. There are several requirements for ensuring that a transaction is a true sale. In determining whether a transaction is a true sale, courts frequently look at the intent of the parties by conducting "an investigation of the true nature of the transaction, examining the parties' practices, objectives, business activities and relationships." ${ }^{, 113}$ Courts often look to the language and form of the transaction to determine whether the intent was to sell or to pledge assets for a secured loan. ${ }^{114}$ The most promi-

112 Labeling a transfer a sale does not in itself make it a true sale:

Recharacterization cases are centuries old. They illustrate that the law may not treat a transaction as a sale just because the buyer and seller labeled it a sale. If the buyer later attempts to enforce its rights as a buyer and someone (usually the seller or its creditors) then challenges the sale as a loan, a court, under certain circumstances, could recharacterize the sale as a loan.

Peter V. Pantaleo, et al., Rethinking the Role of Recourse in the Sale of Financial Assets, 52 BUS. LAW. 159, 164 (1996).

113 Marsha E. Simms, 754 Prac. L. Inst. Com. L. \& Prac. Course Handbook Series 335, 345-46 (1997).

114 Ellis supra note 107, at 305.

[T]rue-sale treatment typically requires that the language and the form of the transaction reflect that the intent of the parties is to sell rather than secure and should refer to sale, not the pledge or grant of a security interest; that the transfer of the assets should be through a formal instrument of transfer, such as an assignment or bill of sale; that the sale should be for a valid business or legal purpose; and the entire purchase price should not be in the form of a promissory note or other indebtedness. Similarly, the transfer of the assets should transfer the burden or risk of loss associated with the assets. Generally, the originator-seller should not warrant, guarantee, or indemnify the purchaser nor permit adjustments to the purchase price for the assets on account of under-performance beyond historical levels of lost collectibility. Providing any mechanism to offset the risk of loss on the assets, such as (i) adding, repurchasing or substituting assets for those conveyed, (ii) providing additional security for losses or grossly overcollateralizing the asset pool vis-à-vis the sale price, or (iii) tying payment for the assets on the performance of the assets will upset any attempt to characterize the transfer of the assets as a sale. Lastly, the transfer of the assets should be treated as a sale for tax, accounting, and business purposes and should be accompanied by notice to third parties affected by the transfer.

Id.

Where other factors are present, the courts will often discuss the language that the parties have used in the document or agreement governing the transaction. Courts focus on terms such as "security" or "collateral" where the other factors indicate a loan, and on terms such as "sale" or "absolutely convey" where other factors support (or do not preclude) sale treatment. For one court, the language in an agreement and conduct of the parties triumphed over full recourse 
nent factor that courts look to is the extent to which the risks and benefits of ownership have been transferred. ${ }^{115}$ In doing so, courts look to the level of recourse the SPV retains against the originator in the case of default, ${ }^{116}$ who retains the benefits of ownership, ${ }^{117}$ how the assets are serviced, ${ }^{118}$ how the

provisions, and the court found a sale. Most courts, however, deemphasize the language used in a document, and consider intent and actual conduct more relevant.

Robert D. Aicher \& William J. Fellerhoff, Characterization of Receivables as a Sale or Secured Loan upon Bankruptcy of the Transferor, 65 AM. BANKR. L.J. 181, 194 (1991).

115 Simms, supra note 113 , at 346.

116 Courts look to see if the owners and the SPV bear the risk of loss or whether the originator bears this risk. Basically, "the greater the recourse the SPV has against the originator, as through chargebacks or adjustments to the purchase price, the more the transfer looks like a loan." Id.

In several decisions courts have considered recourse to the seller for nonpayment of the transferred assets to be suggestive of a loan rather than a sale. This recourse may take the form of a repurchase obligation, a guaranty of collectibility by the seller, a failure to extinguish or reduce an independent obligation for which an "absolute assignment" was made, or a hold back of reserves from the purchase price which are released to the seller only as receivables are paid.

Aicher \& Fellerhoff, supra note 114, at 186.

Recourse to a seller who warrants performance of the asset it sells (i.e., collectibility) should not turn a sale into a loan. Under the case law, however, an absolute promise by the seller to repay the purchase price, with an agreed upon rate of return unrelated to the payment terms of the underlying asset, clearly risks turning a sale into a loan. In recognizing this principle, it is important to understand that the difference between recourse for collectibility and economic recourse is not the difference between a buyer accepting significant financial risk and one who accepts none. In fact, in some situations, the economic bargain between a true buyer of a financial asset who has recourse for collectibility and a lender with economic recourse can be roughly equal. On the one hand, a true buyer, unlike a lender, cannot adjust its return after the purchase to ensure a market return at all times. A buyer, however, would enjoy the upside in value if, for instance, the asset was collected earlier than the parties expected. And so long as the buyer has recourse for collectibility, it could protect itself against the underlying obligor's default.

The real difference between recourse for collectibility and economic recourse is what each says about the type of transaction the parties intended. Recourse for collectibility merely improves the quality of the asset transferred. The purchaser with recourse cannot do better economically than the purchaser without recourse if the asset performs in accordance with its terms. The economic terms of the transaction are defined by the cash flows of the asset itself and collectibility recourse is defined solely by the failure of the asset to perform. On the other hand, economic recourse is some fashion guarantees the return of the purchaser without regard to the economic characteristics of the transferred asset. In the truest sense of the word, the transferred asset serves merely as collateral, as its own financial characteristics do not serve to define the economic terms of the transaction. Transfers with economic recourse look and smell like loans, and because enforcing important state law policies-like prohibiting usury-turned on determining the appropriate characterization of transactions, courts historically have had little hesitation recharacterizing such transfers as loans.

Pantaleo, et al., supra note 112, at 171-72 (Sales with recourse for collectibility are consistent with the concept of a sale and do not bear similarities to a loan, while sales with economic recourse bear similarities to a loan. Recharacterization is appropriate only if there is economic resource).

117 If the originator retains the right to surplus received in excess of the purchase price paid for the assets, or the right to repurchase the assets by paying the purchase price, the originator may appear to have retained the benefits of ownership. Simms, supra note 113, at 346.

In several decisions courts have held that overcollateralization, with a right in the seller to retain eventual collections on accounts over and above a predetermined amount of collections, is evidence of a loan rather than a sale....Courts have sometimes held that the seller's ability to re- 
purchase price is calculated, ${ }^{119}$ and whether account or asset debtors are notified of the transfer. ${ }^{120}$ If a transaction is considered a true sale, it is likely that it is shielded from a possible bankruptcy involving the originator.

ii. Equitable Doctrine of Substantive Consolidation. Without recharacterizing a transaction as a secured loan, a court may still expose the asset or pool of assets in a securitization transaction to bankruptcy proceedings involving the originator by invoking the equitable doctrine of substantive consolidation by determining that the originator and the SPV were functionally interchangeable. ${ }^{121}$ By invoking the doctrine of substantive consolidation, courts are able to disregard the separateness of the SPV and the originator and pool the SPV's assets and liabilities and treat them as if the originator held them. ${ }^{122}$ "[T] $]$ he following two-part balancing test to determine when a substantive consolidation is appropriate: (1) whether there is a 'substantial identity between the entities to be consolidated;' and (2) whether '[substantive] consolidation is necessary to avoid some harm or to realize some benefit." ${ }^{123}$ In determining whether the two entities are inextricably entwined, courts look to several factors including:

gain its prior interest in the accounts through the option of repurchase, by itself or a third party on its behalf, indicated that the transaction was a security device, rather than a sale. The repurchase option has been viewed in other contexts as a retention of potential benefits (as opposed to risks) of the receivables. Aicher \& Fellerhoff, supra note 114, at 192-93.

118 If the SPV or someone other than the originator may not transfer the servicing function, the originator may have retained the benefits of ownership. It is common practice, however, for the originator to continue to act as servicer for a fee, as an agent of the SPV. The originator must service the assets based on agreed upon procedures. Simms, supra note 113, at 347.

A number of courts have noted that the seller's continued servicing of transferred accounts indicates a loan rather than a sale. ... One court has concluded, however, that a mortgage broker's continued servicing of mortgage payments pursuant to an agency agreement among purchasers of interests in the mortgages, which agreement included a separate collection agent fee for the broker, was evidence of a sale.

Aicher \& Fellerhoff, supra note 114, at 191-92.

119 If the purchase price is a fixed price not subject to change as the assets change, "sale characterization is supported." Simms, supra note 113, at 347.

120 If the SPV retains the right to notify the account debtors that the assets or account has been transferred, sale characterization is supported. Id. at 348 .

121 Ellis, supra note 107, at 304-05; Angela Petrucci, Accounting for Asset Securitization in a Full Disclosure World, 30 J. LEGIS. 327, 335 (2004) ("Substantive consolidation, similar to a piercing the corporate veil theory, represents an equitable remedy imposed by bankruptcy courts in which the court will refuse to recognize the separate legal identities of two entities and will effectively consolidate the assets and liabilities of the involved companies.").

122 Simms, supra note 113 , at 350.

123 Petrucci, supra note 121, at 336; Simms, supra note 113, at 350 ("Substantive consolidation is an extraordinary remedy, and should be ordered only if the court finds that the prebankruptcy relationships of the two entities are inextricably entwined, that substantial consolidation would benefit all creditors, and that the creditors did not reasonably rely on the separate existence of each of the parties"). 
(i) the degree of difficulty in segregating assets and liabilities; (ii) the presence of consolidated financial statements; (iii) increased profitability due to consolidation at a single physical location; (iv) commingling of assets and business functions; (v) unity of interests and ownership; (vi) existence of inter-corporate guaranties on loans; and (vii) transfer of assets without observance of corporate formalities. ${ }^{124}$

The second prong requires the court to determine whether substantive consolidation is necessary to avoid some harm or realize a benefit and becomes an equitable determination by the court. ${ }^{125}$ Some courts have decided to add this economic balancing test to the existing factors, while other courts have used this test in place of the historical substantive consolidation test. ${ }^{126}$ By structuring and operating a Special Purpose Vehicle as an independent entity, the likelihood of substantive consolidation is minimized greatly. In order to operate as an independent entity, the Special Purpose Vehicle should comply with formalities, make independent decisions, possess its own assets, manage its own liabilities, maintain separate offices and financial statements, and deal with the originator at arm's length. ${ }^{127}$

iii. Fraudulent Conveyance. The third way that bankruptcy courts can subject a pool of assets to the potential bankruptcy of the originator is by finding that the transfer constitutes a fraudulent conveyance. "[A] transfer is fraudulent if: (1) it was made with an intent to hinder, delay or defraud any creditor, or (2) the transferor received less than reasonably equivalent value for the transfer, and the effect of the transfer was to render the transferor insolvent."

b) Bankruptcy Proof? Eliminating Potential Entity Risks. Entity risks can be virtually eliminated by correctly structuring a Special Purpose Vehicle so that it is restricted from engaging in activities which are unrelated to the securitization or financing transaction. While it is not possible to restrict the Special Purpose Vehicle from filing for bankruptcy, it is possible to limit the risks the Special Purpose Vehicle is allowed to undertake by limiting the rights and powers of directors in the charter establishing the Special Purpose Vehicle. ${ }^{129}$ In general, the Special Purpose Vehicle should only undertake activities that are "necessary or incidental" to the securitiza-

124 Ellis, supra note 107, at 306 n.61, citing In re Vecco Constr. Indus., Inc., 4 B.R. 407, 410 (Bankr. E.D. Va. 1980).

125 Petrucci, supra note 121 , at 336.

126 Ellis, supra note 107, at 306 n.61.

127 Structured Financing Techniques, supra note 7, at 559-60.

128 Simms, supra note 113 , at 351.

129 See Structured Financing Techniques, supra note 7, at 533. 
tion. ${ }^{130}$ The charter of the Special Purpose Vehicle could limit the types of debt the Special Purpose Vehicle can incur to "the asset-backed securities and obligations to credit enhancers and liquidity providers," all of which are necessary or incidental to the transaction. ${ }^{131}$ In addition, the charter of the Special Purpose Vehicle can provide that the underlying assets must be free of all liens, and "cannot be subjected to a voluntary lien or security interest in favor of anyone other than the holders of the asset-backed securities."132 While the charter cannot contain provisions preventing the Special Purpose Vehicle from filing for bankruptcy, the entity can be structured in order to reduce the probability of an involuntary bankruptcy. In order to minimize the risk of an involuntary bankruptcy, the SPV can require consensual creditors to sign an agreement not to file an involuntary bankruptcy claim against the SPV.

While following corporate formalities of the Special Purpose Vehicle and ensuring that the transfer of assets to the Special Purpose Vehicle is considered a true sale will render the securities issued by the SPV saleable in the capital markets, striving to eliminate the possibility that the SPV itself can engage in activities that can potentially expose the pool of assets to bankruptcy proceedings will decrease or eliminate entity risks. In doing so, rating agencies will improve the ratings of securities issued by the SPV proportionately.

\section{Why Firms Securitize their Assets}

The previous section discussed the intricacies of a securitization transaction in order to better understand how a transaction is structured to make it saleable in the capital markets. In doing so, the focus was on minimizing or eliminating the risks which investors could potentially encounter in a securitization transaction. While structuring the transaction in a manner that is attractive to rating agencies and investors is important, it is also important to understand the reasons firms participate in securitization transactions. Without providing firms an incentive for securitizing, it is highly unlikely that an efficient secondary market for a particular type of receivable could be realized.

The determination of whether a firm should securitize is a cost-benefit analysis. If the benefit from securitizing financial assets exceeds the costs associated with doing so, the firm will likely choose to securitize. ${ }^{133}$ Thus, it is important to understand the costs and benefits associated with securitization transactions.

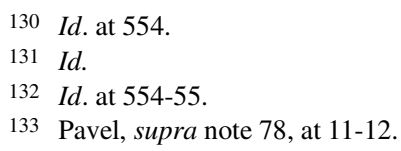


"The primary costs of securitization are the administrative costs, such as the investment banking fee, the fee to the rating agencies, the fee for filing with the Securities and Exchange Commission and the National Association of Securities Dealers, the fee to the trustee, and in some instances, the cost of private insurance."134

The benefits of securitization include reducing risk, increased liquidity and diversification, new and less expensive funding, as well as a potential new source of fee income for originators. ${ }^{135}$ "A company considering securitization should compare (i) the expected differential between interest payable on non-securitized financing and interest payable on securities issued by an applicable SPV with (ii) the expected difference in transaction costs between the alternative funding options." ${ }^{, 136}$

The costs associated with a securitization transaction depend on how the securitization is structured. If the securitization is done by creating a "one-off" securitization structure, the costs of the transaction can be quite high. ${ }^{137}$ However, securitizations can be structured in a manner that minimizes transaction costs by selling the pool of assets to "multiseller securitization conduits." 138 In deciding whether to securitize a pool of assets, firms may look to multiseller securitization conduits in order to minimize the costs associated with the transaction. However, if they seek added flexibility in structuring the transaction, a one-off securitization structure is the better choice.

The most important benefit that firms derive from securitization is that they are able to obtain financing at a lower cost of funds than they normally would if they were to issue securities against the entire firm. An originator whose securities are rated lower than investment grade or not rated at all derive benefits from securitization if the SPV can issue securities that are rated investment grade or higher. ${ }^{139}$ Originators who can issue securities rated investment grade or higher can still derive benefits from securitization if the SPV could issue securities rated higher than the originator's securi-

$134 I d$. at 12 .

135 Id. at 13; George J. Bentson, The Future of Asset Securitization: The Benefits and Costs of Breaking Up the Bank, in THE GlOBAL Asset BACKED SECURITIES MARKET 3, 6 (Stone, et al. eds., 1993).

136 Schwarcz, supra note 60, at 137-38.

137 One-off securitization structures are the most common form of Special Purpose Vehicle. They are Special Purpose Vehicles which are created for a specific securitization transaction. They are normally used because they provide the originator with flexibility to customize the securitization. The costs associated with one-off vehicles are high because they are unable to achieve economies of scale through further securitization of assets. Id. at 138 .

138 Multiseller securitization conduits minimize transaction costs by allowing different originators the opportunity to share a common SPV. These conduits are able to minimize costs by achieving economies of scale through continuous securitization of financial assets. Id. at 140 .

139 Id. at 137. 
ties. $^{140}$ In determining whether an originator receives cost savings from securitization, the interest savings must be weighed against the costs of the securitization transaction.

While a lower cost of funds is essential to enticing firms to securitize their assets, other benefits increase the attractiveness of securitization. First, firms are able to improve their liquidity by transforming illiquid financial assets into cash. "[S]ecuritization converts future income streams into cash, giving companies new funds to apply to opportunities with greater profit potential than what is tied up in past lending decisions." ${ }^{, 141}$ In doing so, they are reducing their exposure to credit risk as well as interest rate risk. By selling off financial assets, firms no longer face the potential risk of interest rates going up making their assets unprofitable. Moreover, they no longer face the potential default of borrowers because this risk has been transferred over to the investors in the securities issued by the SPV. ${ }^{142}$ By not having to face potential repayment risk, firms realize savings since they no longer have to maintain capital reserves guarding against this risk. $^{143}$ Risk reduction plays an integral role in determining whether a firm benefits from securitizing their financial assets or receivables.

\section{ANALYSIS}

In order to ensure that securitization of conventional small business loans is successful, it is important to minimize the asset and entity risks associated with such a transaction. ${ }^{144}$ The solution to minimizing these risks lies in (A) the creation of a government-sponsored entity for the purpose of securitizing conventional small business loans, ${ }^{145}(\mathrm{~B})$ the adoption of credit scoring models in place of relationship underwriting when originators make

\footnotetext{
140 Id.

141 Dvorak, supra note 65, at 549; see also Hill, supra note 19, at 1096-97 (Firms can concentrate on improving origination and servicing of receivables.).

142 Culver, supra note 7, at 36. ("In a properly structured asset securitization, the risk of repayment is transferred completely to the Special Purpose Vehicle and is no longer a contingent liability on the Originator's balance sheet.").

143 Id.

144 Dvorak, supra note 65, at 550.

145 Drawing from the experience of residential mortgages, it becomes apparent that successful securitization has, historically, been the result of the government's involvement in such transactions. See Lisa M. Fairfax, When You Wish Upon a Star: Explaining the Cautious Growth of Royalty-Backed Securitization, 1999 CoLuM. BUS. L. REv. 441, 447-49 (1999). The government's involvement in mortgage securitizations by implicitly and/or explicitly guaranteeing such transactions encouraged investors to invest in securities that were now relatively low-risk investments. Id. In doing so, the government was able to ensure that adequate financing for housing was available as a result of increased securitization. Id.
} 
lending decisions, ${ }^{146}$ and $(\mathrm{C})$ providing credit enhancement in the form of a government guarantee. ${ }^{147}$

\section{A. Creation of a Government-Sponsored Entity}

The driving force behind securitization of home mortgages and other types of financial assets has been the efforts of the United States Government. ${ }^{148}$ In creating government-sponsored entities for the purpose of securitizing home mortgages, Congress single-handedly developed a secondary mortgage market. ${ }^{149}$ At the time Congress created these entities they were faced with a potential housing crisis. ${ }^{150}$ Similarly, small businesses and, in particular, minority owned small businesses currently have inadequate access to conventional small business loans. ${ }^{151}$ While other government efforts, such as the many programs existing under the Small Business Administration, have attempted to bridge the capital gap that exists, it is clear that the solution truly rests in creating an efficient secondary market for conventional small business loans. ${ }^{152}$

\footnotetext{
146 Credit scoring could be used to address the problem of non-uniform underwriting standards because credit-scoring models are a low-cost method of predicting payment performance of small business loans. Board of Governors of the Federal Reserve System, Report to the Congress on the Availability of Credit to Small Businesses, 59 (September 2002), available at http://www.federalreserve.gov/boarddocs/rptcongress/sbc_rep.pdf (hereinafter "Board of Governors") An increasing number of lenders are beginning to use credit-scoring models to underwrite small business loans providing an objective assessment of the risks inherent in the loans. Temkin \& Kormendi, supra note 44, at 10 . However, these credit scoring models are mostly being used for smaller loans meaning that most small business loans are decided by relationship underwriting. Id. This results in lenders not using a standard set of underwriting guidelines. Id. This poses a strong challenge to the development of a secondary market for small business loans since secondary markets normally develop for assets that have common elements, including relatively common underwriting standards, documentation, servicing procedures, and collateral. See id.

147 The Small Business Administration or other government agency can provide less expensive credit enhancement in order to increase the number of feasible conventional small business loan securitizations. Id. Legislation calling for partial guarantees by the SBA of conventional small business loans has been introduced in Congress by Senator Olympia Snowe but has remained stalled in committee. Small Business Credit Liquidity Act of 2003, S. 1713, 108th Cong. (2003), available at http://thomas.loc.gov/cgi-bin/query/z?c108:S.1713:

148 Cosentino, supra note 6, at 544; Bushaw, supra note 6, at 216

149 With the creation of Fannie Mae, Freddie Mac, and Ginnie Mae, and the subsequent securitization of residential mortgages, congress created the secondary market for mortgage loans. $I d$.

150 The secondary mortgage market was created as a result of federal government policy to improve the availability of funds for housing finance. See Shenker \& Colletta, supra note 6, at 1383-84. In 1970, Congress passed the Emergency Home Finance Act of 1970 which created Freddie Mac and augmented the powers of Fannie Mae in response to a near housing crisis. Id. at 1384

151 See generally Blanchflower, et al., supra note 4.

152 Bushaw, supra note 6, at 253. Bushaw provided three potential benefits that governmentsponsored securitization could accomplish, which neither the SBA nor private securitizations have accomplished. Id. First, government support could increase the willingness of investors to participate in small business securitizations. Id. Second, government-sponsored securitization could provide a means by which small banks could participate in securitization of conventional small business loans. Id.
} 
The most effective method of creating an efficient secondary market for small business loans is by creating a government-sponsored entity for the purpose of purchasing and securitizing small business loans. ${ }^{153}$

Such an entity will increase investors' confidence in securities backed by conventional small business loans. ${ }^{154}$ More importantly, such an entity would nearly eliminate all the entity risks associated with securitization transactions. ${ }^{155}$ This would ensure that the loans would not be subject to the potential insolvency of loan originators. This entity would be bankruptcy remote. ${ }^{156}$ Investors will see the Government's participation in these securitizations as an implicit guarantee of the underlying loans. ${ }^{157}$ The Government's involvement will increase the number of investors willing to invest in securities backed by conventional small business loans.

By structuring the entity as a multiseller securitization conduit, cost savings are passed down to firms or originators looking to securitize their conventional small business loans. These cost savings will increase the willingness of banks and other lenders to securitize their conventional small business loans. ${ }^{158}$

Finally, government-sponsored securitization provides credit support that will encourage lenders to make loans to businesses that normally cannot obtain a loan. Id.

153 A Government-Sponsored entity for the purpose of securitizing small business loans would increase marketplace confidence in small business loan pools, provide small banks with a means to securitize their small business loans, and provide credit enhancement to encourage lending to small businesses. Id. Bushaw refers to this type of government involvement as a subsidy. Id. at 256. She fails to mention that the Government-Sponsored entity would recover the costs they incur in providing credit support through fees from the securitization transaction. Even if it is considered a subsidy, the importance of ensuring adequate access to small business loans provides justification for such a subsidy.

154 Historically, government involvement in securitization transactions has been necessary in order to ensure that investors are satisfied with the securities being issued. See id. at 253. "Certainly, there is precedent for government-owned or government-sponsored enterprises doing the research, developing a program and successfully securitizing assets, only to be followed by private pooling of like assets." Id. Thus, the government's involvement would lead the way and provide a blueprint or model for private securitizations to follow. Id.

155 Since a government-sponsored enterprise would be totally independent from the banks and other lenders that originate small business loans, it is unlikely that securitization transactions involving such an enterprise would carry any risk resulting from the potential insolvency of the originator.

156 It is unlikely that a bankruptcy court would recharaterize the transfer of assets as a secured loan, that the assets of the originator of the loans and the GSE are substantively consolidated, or that the transfer was a fraudulent conveyance since a GSE would be completely independent from the originator.

157 Similar to the securities issued by Fannie Mae and Freddie Mac, the securities issued by a government-sponsored enterprise used for securitizing small business loans will not carry an explicit government guarantee. Bushaw, supra note 6, at 217-18. Just as securities issued by Fannie Mae and Freddie Mac are considered to carry an implicit government guarantee, so will securities issued by this government-sponsored enterprise. Id. This results in increased confidence in the securities being issued by the GSE.

158 Specifically, these cost savings benefit smaller banks that are normally least likely to participate in the securitization of small business loans. Id. at 255. In addition, these are the banks that would normally lend to minorities and other types of businesses that face significant lending obstacles and are considered marginal business credits. See id. "A GSE could be structured to ensure that small banks are able to participate in the securitization of their better small business credits." Id. Bushaw argued that 
Creation of a government-sponsored entity whose sole purpose is to purchase and securitize conventional small business loans is the first step towards successful and efficient securitization of conventional small business loans. It is clear that investors will have more confidence in the performance of securities issued by such an entity. It is also clear that the entity risks associated with securitization transactions are eliminated by such an entity. Finally, the entity will create cost savings for loan originators seeking to securitize their loans if it is structured as a multiseller securitization conduit.

\section{B. Adoption of Credit Scoring Models}

In an effective securitization transaction it is important to minimize asset risks, or those risks inherent in the underlying assets being securitized. The first step in eliminating asset risks is carefully selecting the assets. Assets most suitable for securitization are those assets with standardized terms, predictable payment patterns, and uniform underwriting and servicing procedures. For the most part, conventional small business loans do not meet any of these requirements. ${ }^{159}$ Just as was the case with residential mortgages before they were successfully securitized, conventional small business loans do not possess uniform underwriting and servicing procedures. ${ }^{160}$ As a result, it is difficult to predict the payment patterns of a pool of conventional small business loans. ${ }^{161}$ The creation of a governmentsponsored enterprise for the purpose of securitization of conventional small business loans would make conventional small business loans more suitable for securitization. ${ }^{162}$ As discussed above, the successful securitization of residential mortgages by government-sponsored entities resulted in the adoption of uniform underwriting and documentation standards across the mortgage industry. Likewise, creation of a government-sponsored enterprise will cause the small business loan industry to move in a similar direction.

this would impede the progress of private initiatives to pool and securitize loans originated by smaller community banks and that those initiatives should be given some time to satisfy the needs of small banks before Congress steps in. Id. Bushaw's article was written in 1998 and private initiatives have had limited success in securitizing small business loans as evidenced by the lack of adequate access to capital for small businesses.

159 Conventional small business loans are normally heterogeneous, lack standardized loan documentation, and predicting their payment patterns is not possible. Board of Governors, supra note 146, at 36-37.

$160 I d$.

161 Id.

162 Just as mortgages became more suitable for securitization as a result of the implementation of standardized underwriting and documentation standards when the federal government began securitizing them, small business loans will also move towards standardization in order to facilitate their securitization. See Temkin \& Kormendi, supra note 44, at 28. 
Currently, a significant portion of conventional small business loans are decided using relationship underwriting. ${ }^{163}$ As a result, conventional small business loans vary in their terms and quality on a loan to loan basis. ${ }^{164}$ The disparity among conventional small business loans as to their quality and terms make it very difficult to predict the aggregate rate of default on a pool of conventional small business loans. ${ }^{165}$

By adopting credit scoring models designed to ascertain the likelihood of default for a small business, originators of loans will position themselves so that they can efficiently securitize the loans they originate. ${ }^{166}$ Moreover, credit scoring models are mostly automated and would result in significant cost savings to lenders wishing to securitize their conventional small business loans. ${ }^{167}$ In addition, credit scoring models eliminate much of the variance in how loan decisions are made. ${ }^{168}$

Credit scoring models are already in use by many of the larger commercial banks. Moreover, SBA loans are normally all decided using credit scoring models. The SBA subscribes to services provided by Dunn \& Bradstreet and Fair, Isaac and Company, which have become leaders in developing credit scoring software.

An added benefit of adopting credit scoring models is that discrimination in lending markets is diminished since these technologies are automated and do not factor the race of a lender into the decision of whether to approve a loan. Thus, loans that are decided using credit scoring models are decided based on the merits and not the borrower's race.

Some scholars argue that credit scoring disadvantages minority business owners and other disadvantaged borrowers since they are normally less

163 When banks use relationship underwriting, an underwriter makes a decision mostly based on information about a firm and its owner that is gained over time through a business relationship. Id. at 6 . The business relationship may include loans, deposits and other bank products. Id. This type of underwriting allows lenders to look past information such as credit scores and financial statements to deal with information problems better than other types of lenders. Id. This ability to learn more about the firm and its owners allows small banks to continue to dominate small business lending. Id. at 7 . Lenders using relationship underwriting do not adhere to a common set of underwriting standards. Id. at 6 . The SBA conducted discussions with industry participants and determined that relationship underwriting remains prevalent. Id. at 7 .

164 The reasoning behind such a variety in the terms and quality of small business loans is that small businesses are very diverse. Id. at 5 . Their heterogeneity in type of business and in their uses of borrowed funds does not allow for standardized underwriting resulting in underwriting methods that are complex and expensive. Id.

165 Since originators do not follow a common set of underwriting standards, a secondary market for small business loans becomes difficult to create. Id. at 7 . The lack of standardization across small business loans makes it expensive to analyze loan pools in order to predict their rates of default. Id.

166 "Credit scoring is an automated process by which information about an applicant is used to generate a numeric score that indicates the predicted future performance . . of a loan to that applicant." Board of Governors, supra note 146, at 32.

167 Credit scoring is a consistent, inexpensive, and fast way of evaluating credit applications. Id.

168 Since credit scoring models are automated, they eliminate the variation in how risks are assessed across loan officers. Id. 
likely to be approved for loans because of their creditworthiness, or lack thereof. $^{169}$ This argument stems from the fact that relationship underwriting looks past the borrower's credit history and bases the decision of whether to approve on the nature of the business, the borrower's banking relationship, and any number of other factors. ${ }^{170}$ Unfortunately, relationship underwriting has been shown to statistically discriminate against minority business owners. ${ }^{171}$

By using credit scoring to decide loans, originators are using objective methods of making loan decisions and decrease the amount of discrimination in these decisions. ${ }^{172}$ In addition, originators using credit scoring models may begin to originate loans for securitization, making it possible for banks to lend to more borrowers since they now have more funds available. ${ }^{173}$ This could possibly result in lenders lowering the credit standards needed in order to approve a loan since originators are no longer in a position where they must bear the credit risk associated with these loans. This would allow disadvantaged borrowers who are currently declined because of their lack of creditworthiness to be approved for more loans. ${ }^{174}$ As long as the payment patterns are predictable and ascertainable by actuarial analysis, these loans are prime targets for securitization. ${ }^{175}$ The goal is to efficiently allocate risk in the hands of the parties that are most suitable for bearing these risks. In this case, investors in securities backed by small business loans are better suited to bear credit and liquidity risks associated with conventional small business loans than the originators are. In addition, banks and other lending institutions are better suited to originate and service loans than investors in securities backed by the loans are.

A government-sponsored enterprise would require lenders to use uniform underwriting standards in order to securitize their conventional small business loans. Adoption of one of several credit scoring models across the industry would help facilitate the securitization of conventional small business loans by ensuring that loans are decided using uniform underwriting standards making it easier to predict future payment patterns. As a result, discrimination against minorities becomes difficult for lenders to fathom

169 Id. at 35.

170 Temkin \& Kormendi, supra note 44, at 6.

171 See generally Blanchflower, et al., supra note 4.

172 Bushaw, supra note 6, at 249.

173 Board of Governors, supra note 146, at 33. The adoption of credit scoring models provides banks with the necessary uniformity in order to originate loans that provide predictable payment patterns making them suitable for securitization. Id.

174 Board of Governors, supra note 146, at 33. As funds become available to banks as a result of securitization transactions which transfer the credit risk inherent in lending to small businesses to investors who are better equipped to bear risk, they will now seek to lend more in an effort to securitize. Id.

175 See discussion supra Part II.B.1. 
resulting in better access to small business loans for minority business owners.

\section{Government Guarantee of Conventional Small Business Loans}

In minimizing the asset risks involved in a securitization transaction, credit enhancement is normally used. Credit enhancement can be both internal and external to the assets being securitized. ${ }^{176}$ An example of internal credit enhancement is the overcollateralization of the pool of assets. ${ }^{177}$ The most common form of external credit enhancement is recourse to the originator of the assets. ${ }^{178}$ A second type of external credit enhancement is third party recourse. ${ }^{179}$ This type of recourse normally results in no losses to the party issuing the guarantee. ${ }^{180}$

In order to improve the secondary market for conventional small business loans, the United States Government, either acting through the SBA or on its own, should take a second loss position and guarantee the pools of conventional small business loans being securitized. While this type of guarantee is normally reserved for large insurance companies, the guarantee of the U.S. Government will be more effective for many reasons. First, it increases confidence in the securities being issued since they are now guaranteed by the Government. Second, it shows investors that the U.S. Government has done an in-depth analysis of the performance to be expected from the pool of loans and has put its capital at risk after doing so. ${ }^{181}$ Third, it creates cost savings to the originator of the loan since the amount of recourse they normally would face is now lessened to the extent of the Government's guarantee. ${ }^{182}$ Finally, it eliminates asset risks associated with the securitization of conventional small business loans. ${ }^{183}$

This type of government guarantee has already been proposed in the Senate. On October 3, 2003, Senator Olympia J. Snowe of Maine intro-

\footnotetext{
176 Id.

177 Id.

178 Id.

179 Id.

180 Id.

181 See Brewer \& Iseley, supra note 80, at 129. Like other credit enhancers, the Government would do an in-depth analysis of the assets and their risks and rewards. Id. Investors benefit since they could now rely on the analysis undertaken by the Government as a credit enhancer. Id.

182 See Pavel, supra note 78, at 32. The level of credit enhancement is determined by the risk inherent in the assets being securitized. Id. If the Government is willing to guarantee portions of the pool of loans, the originator would now have a lower level of recourse placed on it and thus, would save its capital. $I d$.

183 All forms of credit enhancement are used to eliminate or minimize those risks that are inherent in the assets being securitized. Shenker \& Colletta, supra note 6, at 1379. A guarantee by the Government, which benefits from the Full Faith and Credit Clause of the United States Constitution, could potentially eliminate all of the asset risks in a securitization.
} 
duced the Small Business Credit Liquidity Act of $2003 .^{184}$ The Act authorizes the SBA to provide partial guarantees of pools of conventional small business loans in order to facilitate the securitization of the loans through a pilot program. ${ }^{185}$ Under the pilot program that would be established, the SBA would cover their exposure to potential losses with the fees they collect from providing the guarantee. ${ }^{186}$ Senator Snowe emphasized that the Act would increase access to capital for small business owners and, in particular, that such a program would dramatically improve access to capital for minority-owned small businesses. ${ }^{187}$

Unfortunately, Senator Snowe's proposed legislation has remained stalled in committee and has yet to pass. However, a similar guarantee would be essential to successful securitization of conventional small business loans. Such a guarantee would increase confidence in securities backed by conventional small business loans, would serve an analytical purpose for investors in that the Government would have undertaken an indepth analysis of the underlying assets, and would create incentives for originators of conventional small business loans to securitize their loans.

\section{CONCLUSION}

Securitization of conventional small business loans holds the key to creating adequate access to capital for minority business owners. To date, such securitization has been unsuccessful because of the lack of uniformity in conventional small business loans. Drawing on the experience of the secondary mortgage market, it is clear that securitization of conventional small business loans could only be effective if the Government becomes heavily involved.

First, the Federal Government should create a government-sponsored entity to purchase and securitize conventional small business loans. This entity will result in an implicit guarantee that principal and interest payments will be made in a timely manner. More importantly, it would elimi-

\footnotetext{
184 Senator Snowe's floor statement is available at http://sbc.senate.gov/108bills/creditliquiditystat.pdf (hereinafter "Snowe Statement").

185 Olympia J. Snowe, Small Business Credit Liquidity Act Summary of Provisions, available at http://sbc.senate.gov/108bills/creditliquiditybillprov.pdf. The pilot program proposed by Senator Snowe is a three-year pilot program which facilitates the securitization of small business loans by allowing the SBA to guarantee portions of pools of conventional small business loans. Id.

186 In her floor statement, Senator Snowe specifically stated, "[T]he cost of the SBA guarantees will be fully funded by fees paid by the loan poolers, so no Federal appropriations will be necessary." Snowe Statement, supra note 184 , at 3.

187 Recognizing that minorities face challenges in securing small business loans, Senator Snowe suggested that the opportunities presented by efficient securitization such as lower default risk will provide an incentive for lenders to lend to more small businesses. Id. at 5. Senator Snowe also emphasized that the proposed legislation cannot improve the subjective lending behavior which results in discrimination and poor access to credit for small business loans, but that by providing lenders with incentives to lend to all business owners, minorities benefit proportionately. Id.
} 
nate the entity risks that are associated with the securitization of conventional small business loans. As a result of those efforts, the lending industry will adopt credit scoring models when originating conventional small business loans. This will create uniformity across the industry making securities backed by these loans more attractive to rating agencies and investors. Finally, the U.S. Government should take a second loss position in the securitization of conventional small business loans and guarantee the pools of loans being securitized. This would eliminate many of the asset risks associated with securitization of conventional small business loans. 